\title{
Pengaruh Insentif dan Budaya Kerja Terhadap Komitmen Karyawan Untuk Tetap Bekerja Pada PT Wana Sawit Subur Lestari 2 di Kabupaten Seruyan
}

\author{
Budi Utomo \\ Fakultas Ekonomi dan Bisnis Islam, Prodi Manajemen Bisnis Syariah, Institut Agama Islam Negeri Salatiga, Salatiga, Indonesia \\ Email: budiutomo@iainsalatiga.ac.id \\ Email Penulis Korespondensi: budiutomo@iainsalatiga.ac.id \\ Submitted: 21/11/2021; Accepted: 29/11/2021; Published: 30/11/2021

\begin{abstract}
Abstrak-Penelitian ini bertujuan untuk mengetahui pengaruh insentif dan budaya kerja terhadap komitmen karyawan untuk tetap bekerja pada PT Wana Sawit Subur Lestari 2 di Kabupaten Seruyan. Dengan sampel 81 orang. Pengambilan sampel menggunakan teknik random sampling. Penelitian ini menggunakan metode kuantitatif dengan menggunakan tiga variabel yaitu insentif (X1), budaya kerja (X2), dan komitmen karyawan untuk tetap bekerja (Y). Untuk menganalisis data digunakan uji regresi dan uji korelasi linier sederhana. Teknik pengumpulan data yaitu penyebaran kuesioner, studi kepustakaan, studi lapangan. Hasil analisis penelitian menunjukkan bahwa terdapat pengaruh variabel X1 (insentif) dan X2 (budaya kerja) terhadap komitmen karyawan untuk tetap bekerja pada PT Wana Sawit Subur Lestari 2 di Kabupaten Seruyan, yakni sebesar 34,3\% variasi yang terjadi pada komitmen karyawan untuk tetap bekerja di pengaruhi oleh insentif dan budaya kerja. Sedangkan sisanya sebesar 65,7 $\%$ dipengaruhi oleh faktor lain.
\end{abstract}

Kata Kunci: Insentif; Budaya Kerja; Komitmen Karyawan Untuk Tetap Bekerja

Abstract-The study aims to determine the effect of incentives and work culture of the employees commitment to keep working on sustainable luch PT Wana Sawit Subur Lestari 2 in Seruyan. With a sample of 81 people. Sampling using random sampling. This study uses quantitative methods using three variables incentives, work culture, and employee commitment to keep working. To analyze the data used regression and simple linier correlation test. Data collection techniques are questionnaire literature studies, field studies. Result of analyze showed that there are significant incentives variable, and the work culture of the employees' commitment to keep working on sustainable luch PT Wana Sawit Subur Lestari 2 in distrik Seruyan. 34,3\% of the variation that occurs on the employee's commitment to keep working is influenced by incentives and work culture. While the remaining $65,7 \%$ is influenced by other factor.

Keywords: Incentives; Work Culture; Employees' Commitment to Keep Working

\section{PENDAHULUAN}

Seiring dengan perubahan era globalisasi saat ini dan dalam kondisi masyarakat sekarang, sering kali ditemukan beberapa permasalahan yang menyebabkan banyak perusahaan mengalami kegagalan, baik yang disebabkan oleh ketidak mampuan beradaptasi dengan kemajuan teknologi maupun yang disebabkan oleh kurang baiknya hasil kerja dari sumber daya manusia yang ada pada perusahaan tersebut, padahal harus diakui manusia adalah faktor penting yang turut menentukan keberhasilan suatu perusahaan. Oleh karena itu, keberhasilan suatu perusahaan atau organisasi sangat ditentukan oleh kegiatan pendayagunaan sumberdaya manusia yaitu orang-orang yang menyediakan tenaga, bakat kreativitas dan semangat bagi perusahaan serta memegang peranan penting dalam fungsi operasional perusahaan.

Untuk dapat mengikuti segala perkembangan yang ada dan tercapainya tujuan suatu perusahaan maka perlu adanya suatu motivasi agar pegawai mampu bekerja dengan baik, dan salah satu motivasi itu adalah dengan memenuhi keinginan-keinginan pegawai antara lain: gaji atau upah yang baik, pekerjaan yang aman, suasana kerja yang kondusif, penghargaan terhadap pekerjaan yang dilakukan, pimpinan yang adil dan bijaksana, pengarahan dan perintah yang wajar, organisasi atau tempat kerja yang dihargai masyarakat atau dengan mengupayakan insentif yang besarnya proporsioanal dan bersifat progresif yang artinya sesuai dengan jenjang karir, karena insentif sangat diperlukan untuk memacu kinerja para pegawai agar selalu berada pada tingkat tertinggi (optimal) sesuai kemampuan masing-masing. Apabila insentif dikelola secara benar, maka akan membantu organisasi mencapai tujuan-tujuannya. Disamping juga memperoleh, memelihara, dan mempertahankan tenaga kerja yang produktif. Jika dikelola secara tidak benar insentif dapat menyebabkan pegawai mengurangi upaya-upaya mereka atau dengan mencari pekerjaan alternatif lainnya. Untuk menahan pegawai yang baik, pihak atasan hendaknya memerhatikan dan memastikan bahwa terdapat kewajaran dalam pemberian insentif di dalam organisasi demi kesejahteraan pegawai dan meningkatkan produktivitas kinerjanya.

Menurut Rivai (2005:384), "Insentif diartikan sebagai bentuk pembayaran yang dikaitkan dengan kinerja gainsharing, sebagai pembagian keuntungan bagi karyawan akibat peningkatan produktivitas atau penghematan biaya. Sistem pemberian insentif menurut Rivai (2005:387), sebagai berikut: Bonus tahunan,Insentif langsung, Insentif individu, Insentif tim, Pembagian keuntungan, bagi hasil.

Menurut Triguno (2002:3) budaya kerja adalah suatu falsafah yang didasari oleh pandangan hidup sebagai nilai-nilai yang menjadi sifat, kebiasaan dan kekuatan pendorong, membudaya dalam kehidupan suatu kelompok masyarakat atau organisasi, kemudian tercermin dari sikap menjadi perilaku, kepercayaan cita-cita, pendapat dan 
tindakan yang terwujud sebagai 'kerja' atau 'bekerja'. Budaya kerja sebagai kebiasaan yang dilakukan karyawan dalam suatu lembaga atau instansi yang mengandung nilai-nilai yang membudaya.

Menurut Potter dalam Panggabean (2002:127), komitmen adalah kuatnya pengenalan dan keterlibatan seseorang dalam suatu organisasi tertentu. Becker dalam Panggabean (2002:127) menggambarkan komitmen sebagai kecenderungan untuk terikat dalam kegiatan yang konsisten karena menganggap adanya biaya pelaksanaan yang lain (berhenti bekerja).

Komitmen karyawan pada perusahaan diantaranya ditentukan oleh insentif dan budaya kerja pada perusahaan. Jika tidak sesuai ditakutkan karyawan akan menurunkan performa kerjanya dan keluar mencari perusahan lain. Konsistensi kerja karyawan merupakan salah satu faktor penentu tercapainya tujuan perusahaan. Karyawan yang memiliki konsistensi kerja yang tinggi diharapkan dapat memberikan kontribusi yang sangat baik bagi perusahaan. Komitmen karyawan terhadap organisasi atau dalam banyak literatur berbahasa Indonesia disebut juga dengan istilah komitmen organisasi, didefinisikan oleh Porter sebagai kekuatan yang bersifat relatif dari individu dalam mengidentifikasikan keterlibatan dirinya ke dalam bagian organisasi. Hal ini ditandai dengan tiga hal, yaitu penerimaan terhadap nilai-nilai dan tujuan organisasi, kesiapan dan kesediaan untuk berusaha dengan sungguh-sungguh atas nama organisasi, dan keinginan untuk mempertahankan keanggotaannya di dalam organisasi atau dengan kata lain menjadi bagian dari organisasi (Mowday, Porter \& Steers, 1982).

PT. Wana Sawit Subur Lestari II merupakan perusahaan yang bergerak dalam industri kelapa sawit, yang hasil produksinya berupa minyak mentah, sebagian besar dipasarkan ke luar negeri. Dalarn menjaga kualitas produk perusahaan mempersiapkan sumberdaya manusia yang potensial salah satunya dengan memberikan insentif, membina komitmen karyawan untuk dapat bersikap dan berperilaku sesuai sistem nilai organisasi dalarn rangka mewujudkan tujuan perusahaan. komitmen karyawan atau komitmen anggota terhadap organisasi (employee commitment to organization, ECO), dimana perusahaan mempersiapkan karyawannya untuk berpikir positif dan berperilaku produktif bagi kepentingan perusahaan yang tentunya sangat berpengaruh terhadap komitmen kerja karyawan.

\section{METODE PENELITIAN}

\subsection{Populasi dan Sampel}

Penelitian menggunakan penelitian kuantitatif. dilakukan di PT.Wana Sawit Subur Lestari Kabupaten Seruyan Kalimantan Tengah. Populasi dalam penelitian ini adalah seluruh karyawan PT Wana Sawit Subur Lestari 2 bagian supervisi 1.164 karyawan dan sampel pada penelitian ini setelah dihitung dengan menggunakan rumus Slovin sebanyak 81 responden.

\subsection{Insentif}

Insentif sebagai sarana motivasi yang mendorong para pegawai untuk bekerja dengan kemampuan yang optimal, yang dimaksudkan sebagai pendapatan ekstra di luar gaji atau upah yang telah di tentukan. Pemberian insentif dimaksudkan agar dapat memenuhi kebutuhan para pegawai dan keluarga mereka. Istilah sistem insentif pada umumnya digunakan untuk menggambarkan rencana - rencana pembayaran upah yang dikaitkan secara langsung atau tidak langsung dengan berbagai standar kinerja pegawai atau profitabilitas organisasi.

Insentif dapat dirumuskan sebagai balas jasa yang memadai kepada pegawai yang prestasinya melebihi standar yang telah ditetapkan. Insentif merupakan suatu faktor pendorong bagi pegawai untuk bekerja lebih baik agar kinerja pegawai dapat meningkat. Pangabean (2002: 77 ) mengemukakan bahwa "Insentif merupakan imbalan langsung yang dibayarkan kepada karyawan karena prestasi melebihi standar yang ditentukan. Dengan mengasumsikan bahwa uang dapat mendorong karyawan bekerja lebih giat lagi, maka mereka yang produktif lebih menyukai gajinya dibayarkan berdasarkan hasil kerja". Menurut Mangkunegara ( 2002 : 89) mengemukakan bahwa " Insentif adalah suatu bentuk motivasi yang dinyatakan dalam bentuk uang atas dasar kinerja yang tinggi dan juga merupakan rasa pengakuan dari pihak organisasi terhadap kinerja karyawan dan kontribusi terhadap organisasi ( perusahaan )."

Begitu pula menurut Handoko ( 2002 : 176 ) mengemukakan bahwa " Insentif adalah perangsang yang ditawarkan kepada para karyawan untuk melaksanakan kerja sesuai atau lebih tinggi dari standar - standar yang telah ditetapkan". Jadi menurut pendapat - pendapat para ahli di atas dapat disimpulkan, bahwa Insentif adalah dorongan pada seseorang agar mau bekerja dengan baik dan agar lebih dapat mencapai tingkat kinerja yang lebih tinggi sehingga dapat menambah kemauan kerja dan motivasi seorang pegawai agar terciptanya suatu kinerja yang berkualitas sesuai dengan tujuan perusahaan.

\subsection{Budaya Kerja}

Budaya organisasi mewakili persepsi umum yang dimiliki oleh anggota organisasi. Situasi dan kondisi ini akan terasa lebih jelas apabila budaya organisasi diartikan sebagai suatu sistem pengertiann bersama. Dalam konteks budaya kerja, maka terlebih dahulu dapat dijelaskan menurut asal usul katanya. Secara etimologis, budaya berasal dari bahasa Sanskerta "buddhayah", sebagai bentuk jamak dari kata dasar "budhi", yang berarti akal atau segala 
sesuatu yang berkaitan dengan akal pikiran, nilai-nilai dan sikap mental. Budidaya mengandung arti memberdayakan budi sebagaimana dalam bahasa Inggris dikenal sebagai culture (Latin-colere) yang semua artinya mengolah atau mengerjakan sesuatu (mengolah tanah pertanian),kemudian berkembang sebagai cara manusia mengaktualisasikan nilai (value), karsa (creativity) dan hasil karya (performance).

Schein (1991: 93) mendifinisikan budaya sebagai: "Suatu pola asumsi dasar yang dimiliki bersama oleh kelompok untuk memecahkan masalah penyesuaian eksternal dan integrasi internal. Pola yang berhasil dan dianggap sah cenderung akan diajarkan kepada anggota baru sebagai cara yang tepat untuk menerima, berpikir, dan merasa berhubungan dengan masalah tersebut".

Menurut Kemenpan RI (2002) adalah cara kerja sehari-hari yang bermutu dan selalu mendasari nilai-nilai yang penuh makna sehingga menjadi motivasi, memberi inspirasi, untuk senantiasa bekerja lebih baik, dan memuaskan bagi masyarakat yang dilayani. Secara praktis bahwa budaya kerja mengandung beberapa pengertian (Kemenpan RI, 2002):

a. Ada pola nilai, sikap, tingkah laku, hasil karsa dan karya termasuk segala instrument, sistem kerja, teknologi dan bahasa yang digunakannya.

b. Budaya berkaitan erat dengan persepsi terhadap nila-nilai dan lngkungannya yang melahirkan karya dan pandangan hidup, yang akan mempengaruhi sikap dan tingkah laku dalam bekerja.

c. Budaya merupakan hasil dari pengalaman hidup, kebiasaan-kebiasaan serta proses seleksi (menerima atau menolak) norma yang ada dengan cara berinteraksi sosial atau menempatkan dirinya ditengah-tengah lingkungan kerja tertentu.

d. Dalam proses budaya terdapat saling memengaruhi dan saling ketergantungan (interdependensi) baik sosial maupun lingkungan non sosial.

Sementara itu menurut Triguno (2002:3) budaya kerja adalah suatu falsafah yang didasari oleh pandangan hidup sebagai nilai-nilai yang menjadi sifat, kebiasaan dan kekuatan pendorong, membudaya dalam kehidupan suatu kelompok masyarakat atau organisasi, kemudian tercermin dari sikap menjadi perilaku, kepercayaan cita-cita, pendapat dan tindakan yang terwujud sebagai 'kerja' atau 'bekerja'.

Menurut Triguno (2002 : 6-7) mengungkapkan bahwa "masuknya nilai-nilai budaya kerja dalam manajemen dapat meningkatkan kualitas sumberdaya manusia, kualitas cara kerja dan kualitas produknya. Lebih jauh Amstrong (dalam Sudarmanta, 2009:182) menekankan bahwa budaya dapat menciptakan lingkungan kerja yang kondusif untuk perbaikan kinerja dan manajemen perubahan. Hal ini didukung juga dengan penjelasan Cameron dan Quin (dalam Sudarmanto, 2009:182) yang menggambarkan budaya memiliki efek (pengaruh sangat kuat terhadap kinerja dan efektivitas organisasi jangka panjang.

Berdasarkan pendapat paramita (Ndraha, 2005:208) yang mengatakan bahwa budaya kerja dapat dibagi menjadi: 1) Sikap terhadap pekerjaan, yakni kesukaan akan kerja dibandingkan kegiatan lain, seperti bersantai, atau semata-mata memperoleh kepuasan dari kesibukan pekerjaannya sendiri, atau terpaksa melakukan sesuatu hanya untuk kelangsungan hidupnya; dan 2) Perilaku pada waktu bekerja, seperti rajin, berdedikasi, bertanggung jawab, berhati-hati, teliti, cermat kemauan yang kuat untuk mempelajari tugas dan kewajibannya, suka membantu sesama karyawan atau sebaliknya.

\subsection{Komitmen Karyawan Untuk Tetap Bekerja}

Menurut Sunarto (2005:25), komitmen adalah kecintaan dan kesetiaan terdiri dari:

1. Pernhataan dengan tujuan dan nilai-nilai perusahaan

2. Keinginan untuk tetap berada dalam organisasi.

3. Kesediaan untuk bekerja keras atas nama organisasi.

Menurut Potter dalam Panggabean (2002:127), komitmen adalah kuatnya pengenalan dan keterlibatan seseorang dalam suatu organisasi tertentu. Becker dalam Panggabean (2002:127) menggambarkan komitmen sebagai kecenderungan untuk terikat dalam gars kegiatan yang konsisten karena menganggap adanya biaya pelaksanaan yang lain. (berhenti bekerja). Menurut Griffin \& Bateman dalam Munandar (2004:75), menyebutkan bahwa komitmen organisasi adalah:

1. Dambaan pribadi untuk mempertahankan keangotannya dalam organisasi.

2. Keyakinan dan penerimaan terhadap nilai dan tujuan organisasi.

3. Kemauan secara sadar untuk mencurahkan usaha demi kepentingan organisasi.

Menurut Allen dan Meyer (Panggabean, 2002:135) menjelaskan 3 bentuk dimensi dari komitmen organisasi yang dapat dijadikan sebagai indikator antara lain sebagai berikut:

a. Affective Commitment, Tingkatan seseorang karyawan secara emosi terikat mengenal dan terlibat dalam organisasi.

b. Continuance Commitment, Persepsi nilai yang dimiliki oleh karyawan berdasarkan yang didapat dan dikorbankan secara psikologis, sosial, fungsional, dan ritual

c. Normative Commitment, Tingkatan seseorang secara psikologi terikat untuk menjadi karyawan dari sebuah organisasi yang didasarkan perasaan, kesetiaan, kehangatan, pemilikan, dan lain-lain. 


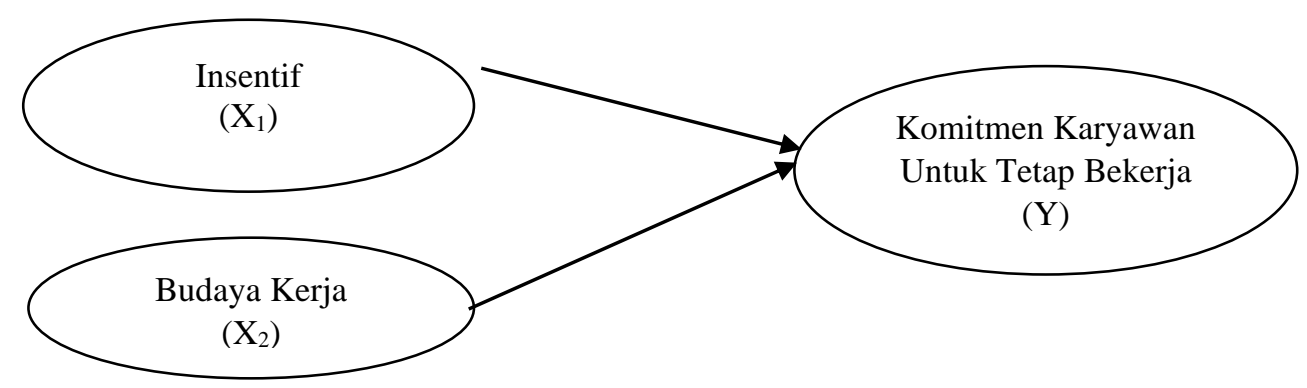

Gambar 1. Model Penelitian

Tabel 1. Daftar variabel dan Indikator Penelitian

\begin{tabular}{|c|c|c|c|}
\hline No & Variabel & Sub Variabel & Indikator \\
\hline 1. & $\begin{array}{l}\text { Insentif (X1) } \\
\text { (Mangkunegara, } \\
\text { 2002:89) }\end{array}$ & $\begin{array}{l}\text { a. Tujuan } \\
\text { b. Progam dan } \\
\text { pelaksanaan } \\
\text { c. Tanggapan } \\
\text { responden terhadap } \\
\text { pemberian insentif } \\
\text { d. Evaluasi }\end{array}$ & $\begin{array}{l}\text { a. Tujuan pemberian insentif } \\
\text { b. Bagaimana program dan pemberian insentif } \\
\text { pada perusahaan } \\
\text { c. Bonus tahunan, insentif langsung, insentif tim } \\
\text { d. membandingkan antara program dengan } \\
\text { pelaksanaan pemberian insentif pada } \\
\text { perusahaan. }\end{array}$ \\
\hline 2. & $\begin{array}{l}\text { Budaya Kerja (X2) } \\
\text { (Mangkuprawira,2009) }\end{array}$ & a. Dedikasi/loyalitas & $\begin{array}{l}\text { a. Memiliki sikap yang selalu memegang teguh visi } \\
\text { misi yang disertai sikap konsisten, kerja sama, } \\
\text { dan dapat dipercaya. } \\
\text { b. Menerapkan sikap melalui proses perencanan, } \\
\text { kedisiplinan, ketekunan dan didukung dengan } \\
\text { rasa tanggung jawab yang tinggi } \\
\text { c. Selalu memegang teguh komitmen, jujur dan dapat } \\
\text { menjadi panutan }\end{array}$ \\
\hline 3. & $\begin{array}{l}\text { Komitmen Karyawan } \\
\text { (Y) } \\
\text { (Panggabean, } \\
2002: 135 \text { ) }\end{array}$ & $\begin{array}{ll}\text { a. } & \text { Affective } \\
& \text { Commitment } \\
\text { b. } & \text { Continuance } \\
& \text { Commitment } \\
\text { c. Normative } & \text { Commitment }\end{array}$ & $\begin{array}{l}\text { a. Tingkatan seseorang karyawan secara emosi } \\
\text { terikat mengenal dan terlibat dalam organisasi } \\
\text { b. Persepsi nilai yang dimiliki oleh karyawan } \\
\text { berdasarkan yang didapat dan dikorbankan secara } \\
\text { psikologis, sosial, fungsional, dan ritual } \\
\text { c. Tingkatan seseorang secara psikologi terikat } \\
\text { untuk menjadi karyawan dari sebuah organisasi } \\
\text { yang didasarkan perasaan, kesetiaan, kehangatan, } \\
\text { pemilikan, dan lain-lain }\end{array}$ \\
\hline
\end{tabular}

\section{HASIL DAN PEMBAHASAN}

\subsection{Uji Instrumen}

\subsubsection{Uji Validitas dan Uji Reliabilitas}

Pengujian validitas dari reliabilitas merupakan proses pengujian terhadap instrument yang akan dipergunakan memperoleh data sesuai dengan kerangka pikir pada penelitian ini maka hasil dari uji validitas dan uji reliabilitas akan memberikan gambaran keterpaduan antara item atau butir yang digunakan dalam satu variabel dan keselarasan atas jawaban atau respon yang diberikan responden atau kuesioner yang dipergunakan dalam penelitian. Pengujian ini dilakukan dengan menyebar kuisioner kepada 81 orang responden.

\subsubsection{Uji Validitas Instrumen}

Dengan menggunakan bantuan software spss release 20 for windows, validitas instrument dinyatakan dalam nilainilai hasil analisis skor tiap-tiap butir terhadap nilai totalnya. Apabila nilai skor total menunjukkan nilai positif atau bertanda * berarti butir tersebut memiliki korelasi yang valid pada taraf signifikan $5 \%(0,05)$ atau bertanda ${ }^{* *}$ berarti valid pada taraf signifikan $1 \%(0,01)$, jika semua butir telah lolos uji validitas selanjutnya ditentukan ke pengujian reliabilitas. 


\section{Insentif}

Variabel insentif diukur dengan 5 butir pertanyaan. Jawaban semua butir mempunyai validitas yang besar. Dari pengujian validitas butir terhadap variabel insentif yang yang terdapat 5 butir pertanyaan diketahui bahwa semua butir dinyatakan valid. Untuk lebih jelasnya koefisien korelasi dapat dilihat secara jelas pada tabel 2

Tabel 2. Uji Validitas Butir Variabel Insentif

\begin{tabular}{ccccc} 
& No Butir & Koefisien Korelasi & Signifikan & Keterangan \\
\cline { 2 - 4 } & 1. & $0,622^{* *}$ & 0,000 & Valid \\
2. & $0,513^{* *}$ & 0,000 & Valid \\
3. & $0,856^{* *}$ & 0,000 & Valid \\
Keterangan & 5. & $0,802^{* *}$ & 0,000 & Valid \\
& $:{ }^{*}$ Signifikan dengan tingkat kesalahan 5\% & \\
& $:{ }^{* *}$ Signifikan dengan tingkat kesalahan 1\% &
\end{tabular}

\section{Budaya Kerja}

Variabel budaya kerja diukur dengan 6 butir pertanyaan. Jawaban semua butir mempunyai validitas yang besar. Dari pengujian validitas butir terhadap variabel budaya kerja yang terdapat 6 butir pertanyaan diketahui bahwa semua butir dinyatakan valid. Untuk lebih jelasnya koefisien korelasi dapat dilihat secara jelas pada tabel 3

Tabel 3. Validitas Butir Variabel Budaya Kerja

\begin{tabular}{cccc}
\hline No Butir & Koefisien Korelasi & Signifikan & Keterangan \\
\hline 1. & $0,527^{* *}$ & 0,000 & Valid \\
2. & $0,525^{* *}$ & 0,000 & Valid \\
3. & $0,717^{* *}$ & 0,000 & Valid \\
4. & $0,806^{* *}$ & 0,000 & Valid \\
5. & $0,727^{* *}$ & 0,000 & Valid \\
6. & $0,540^{* *}$ & 0,000 & Valid \\
\hline Keterangan & $:{ }^{*}$ Signifikan dengan tingkat kesalahan $5 \%$ &
\end{tabular}

\section{Komitmen Karyawan Untuk Tetap Bekerja}

Variabel komitmen karyawan untuk tetap bekerja diukur dengan 12 butir pertanyaan. Jawaban semua butir mempunyai validitas yang besar. Dari pengujian validitas butir terhadap variabel komitmen karyawan untuk tetap bekerja yang terdapat 12 butir pertanyaan diketahui bahwa semua butir dinyatakan valid. Untuk lebih jelasnya koefisien korelasi dapat dilihat secara jelas pada tabel 4.

Tabel 4. Uji Validitas Butir Variabel Komitmen Karyawan Untuk Tetap Bekerja

\begin{tabular}{cccc}
\hline No Butir & Koefisien Korelasi & Signifikan & Keterangan \\
\hline 1. & $0,400^{* *}$ & 0,000 & Valid \\
2. & $0,550^{* *}$ & 0,000 & Valid \\
3. & $0,648^{* *}$ & 0,000 & Valid \\
4. & $0,610^{* *}$ & 0,000 & Valid \\
5. & $0,510^{* *}$ & 0,000 & Valid \\
6. & $0,439^{* *}$ & 0,000 & Valid \\
7. & $0,543^{* *}$ & 0,000 & Valid \\
8. & $0,654^{* *}$ & 0,000 & Valid \\
9. & $0,662^{* *}$ & 0,000 & Valid \\
10. & $0,580^{* *}$ & 0,000 & Valid \\
11. & $0,497^{* *}$ & 0,000 & Valid \\
12. & $0,631^{* *}$ & 0,000 & Valid \\
\hline
\end{tabular}

Keterangan $\quad:{ }^{*}$ Signifikan dengan tingkat kesalahan 5\%

$:{ }^{* *}$ Signifikan dengan tingkat kesalahan $1 \%$

\subsubsection{Uji Reliabilitas Instrumen}

\section{Insentif}

Pengujian reliabilitas di dalam penelitian ini bertujuan untuk mengukur apakah jawaban yang diberikan responden konsisten atau keselarasan dalam merespon per item yang terdapat pada kuisioner penelitian. Dengan kata lain alat pengukuran apakah alat pengukuran bisa dipercaya atau bisa diandalkan. Dari hasil uji validitas, item-item pernyataan dan indikator yang dinyatakan valid diukur reliabilitasnya atau keandalannya dengan bantuan computer program SPSS versi 20. Hasil pengukuran uji reliabilitas insentif ditunjukkan pada tabel 5 
Ekonomi, Keuangan, Investasi dan Syariah (EKUITAS)

Vol 3, No 2, November 2021, Hal 226-234

ISSN 2685-869X (media online)

DOI 10.47065/ekuitas.v3i2.1124

Tabel 5. Hasil Uji Reliabilitas Instrumen Variabel Insentif

\begin{tabular}{cccc}
\hline No & Alpha if Item Deleted & Nilai Kritis & Keterangan \\
\hline 1. & 0,737 & 0,6 & Reliabel \\
2. & 0,766 & 0,6 & Reliabel \\
3. & 0,592 & 0,6 & Reliabel \\
4. & 0,631 & 0,6 & Reliabel \\
5. & 0,693 & 0,6 & Reliabel \\
\hline \multicolumn{4}{r}{}
\end{tabular}

Dari tabel di atas nilai alpha if item deleted menunjukkan nilai lebih dari 0,6. Maka item pertanyaan dikatakan reliabel.

\section{Budaya Kerja}

Dari hasil uji validitas, item-item pernyataan dan indikator yang dinyatakan valid diukur reliabilitasnya atau keandalannya dengan bantuan computer program SPSS versi 20. Hasil pengukuran uji reliabilitas budaya kerja ditunjukkan pada tabel

Tabel 6. Hasil Uji Reliabilitas Instrumen Variabel Budaya Kerja

\begin{tabular}{cccc}
\hline No & Alpha if Item Deleted & Nilai Kritis & Keterangan \\
\hline 1. & 0,770 & 0,6 & Reliabel \\
2. & 0,637 & 0,6 & Reliabel \\
3. & 0,562 & 0,6 & Reliabel \\
4. & 0,552 & 0,6 & Reliabel \\
5. & 0,560 & 0,6 & Reliabel \\
6. & 0,643 & 0,6 & Reliabel \\
\hline \multicolumn{4}{c}{ Sumber : Perhitungan SPSS 20 }
\end{tabular}

Dari tabel di atas nilai alpha if item deleted dari item 1 sampai item 6 menunjukkan nilai lebih dari 0,6. Maka item pertanyaan dikatakan reliabel.

\section{Komitmen Karyawan Untuk Tetap Bekerja}

Dari hasil uji validitas, item-item pernyataan dan indikator yang dinyatakan valid diukur reliabilitasnya atau keandalannya dengan bantuan computer program SPSS versi 20. Hasil pengukuran uji reliabilitas komitmen karyawan untuk tetap bekerja ditunjukkan pada tabel dibawah ini.

Tabel 7. Hasil Uji Reliabilitas Kryawan Untuk Tetap Bekerja

\begin{tabular}{cccc}
\hline No & Alpha if Item Deleted & Nilai Kritis & Keterangan \\
\hline 1. & 0,800 & 0,6 & Reliabel \\
2. & 0,787 & 0,6 & Reliabel \\
3. & 0,775 & 0,6 & Reliabel \\
4. & 0,779 & 0,6 & Reliabel \\
5. & 0,790 & 0,6 & Reliabel \\
6. & 0,799 & 0,6 & Reliabel \\
7. & 0,788 & 0,6 & Reliabel \\
8. & 0,777 & 0,6 & Reliabel \\
9. & 0,773 & 0,6 & Reliabel \\
10. & 0,782 & 0,6 & Reliabel \\
11. & 0,790 & 0,6 & Reliabel \\
12. & 0,777 & 0,6 & Reliabel \\
\hline \multicolumn{4}{c}{ Sumber : Perhitungan SPSS 20 } \\
\hline
\end{tabular}

Dari tabel di atas nilai alpha if item deleted dari item 1 sampai 12 menunjukkan nilai lebih dari 0,6. Maka item pertanyaan dikatakan reliabel.

\subsubsection{Uji Asumsi Klasik}

Secara statistik model persamaan regresi yang diajukan beserta hasil pengujian hipotesisnya sudah dapat dikatakan memenuhi syarat, dalam arti eratnya hubungan antara variabel bebas (terikat). Akan tetapi agar model persamaan tersebut dapat diterima secara ekonometrika dari estimator-estimator yang diperoleh dengan metode kuadrat terkecil (OLS) sudah memenuhi syarat Best Linier Unbiast (BLUE) maka harus juga memenuhi asumsi antara lain bebas dari multikolonieritas, heteroskedastisitas, dan otokorelasi. 


\subsubsection{Uji Normalitas}

Uji normalitas bertujuan untuk menguji apakah dalam sebuah model regresi, variabel dependen, variabel independen atau keduanya memiliki distribusi normal atau tidak. Model regresi yang baik adalah distribusi data normal/mendekati normal. Dari analisis grafik dapat dilihat normalitas yaitu dengan melihat grafik histogram yang membandingkan antara data observasi dengan distribusi yang mendekati distribusi normal.

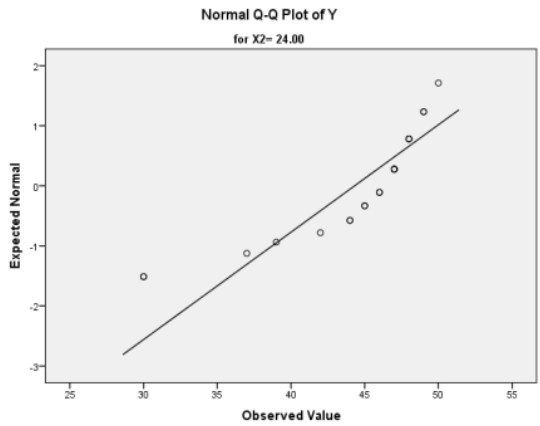

Gambar 2. Uji Normalitas Data

\subsubsection{Uji Multikolonieritas}

Salah satu model regresi klasik adalah tidak terjadinya multikolonieritas antara sesama variabel bebas yang ada dalam model atau dapat dikatakan tidak adanya hubungan linier yang sempurna antara variabel bebas yang ada dalam model. Berdasarkan pada hitungan matrik korelasi dengan menggunakan software SPSS versi 20 dapat diketahui adanya hubungan multikolonieritas diantara variabel bebas melalui Variance Inflation Variabel (VIF) yang didapatkan seperti pada tabel 8.

Tabel 8. Nilai Variance Inflation (VIF)

\begin{tabular}{|c|c|c|c|}
\hline \multicolumn{4}{|c|}{ Coefficients $^{\mathrm{a}}$} \\
\hline \multirow[t]{2}{*}{ Model } & & \multicolumn{2}{|c|}{ Collinearity Statistics } \\
\hline & & Tolerance & VIF \\
\hline \multirow{2}{*}{1} & $\mathrm{X} 1$ & .939 & 1.065 \\
\hline & $\mathrm{X} 2$ & .939 & 1.065 \\
\hline
\end{tabular}

Hasil pengujian menunjukkan tidak adanya multikolonieritas sebagaimana yang ditunjukkan oleh masingmasing nilai VIF variabel bebas yang menunjukkan nilai lebih kecil dari 10 sehingga pada model tidak terjadi multikolonieritas.

\subsubsection{Uji Heteroskedastisitas}

Uji asumsi klasik regresi berganda heteroskedastisitas memiliki tujuan menguji apakah dalam sebuah model rgresi terjadi ketidak samaan varians residual dari suatu pengamatan ke pengamatan lainnya tetap, maka disebut homokedastisitas dan jika varians berbeda disebut heteroskedastisitas.

Deteksi ada tidaknya heteroskedastisitas dapat dilakukan dengan melihat ada tidaknya pola tertentu pada scatterplot diagram dimana sumbu $\mathrm{X}$ dan $\mathrm{Y}$ yang telah diprediksi dan $\mathrm{X}$ adalah residual ( $\mathrm{Y}$ prediksi- $\mathrm{Y}$ sesungguhnya yang telah di Studentized. Dari hasil pengolahan data yang dilakukan pada gambar 2

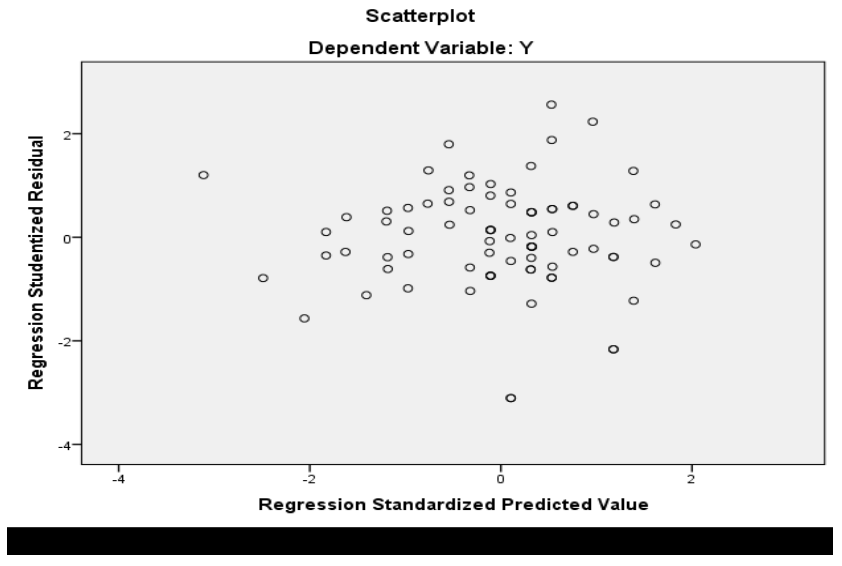

Gambar 2. Hasil Uji Heteroskedastisitas 


\subsubsection{Hasil Uji Heteroskedastisitas}

Dari scatterplot diagram terlihat titik-titik menyebar secara acak, tidak memeluk suatu pola tertentu jelas serta tersebar baik diatas maupun di bawah angka 0 pada sumbu Y. Hal ini berarti tidak terjadi heteroskedastisitas pada model regresi penelitian ini.

\subsubsection{Uji autokorelasi}

Untuk mengetahui ada tidaknya autokorelasi pada model regresi yang digunakan maka dilakukan uji autokorelasi yang didasarkan atas (Santoso, 2000):

a. Jika angka D-W (Durbin- Watson) diatas 2 berarti terdapat autokorelasi positif.

b. Jika angka D-W (Durbin Watson) diantara -2 sampai dengan 2 berarti tidak terdapat autokorelasi.

c. Jika angka D-W (Durbin Watson) dibawah 2 berarti terdapat autokorelasi negatif.

Tabel 9. Nilai Durbin Watson

\begin{tabular}{|c|c|c|c|c|c|}
\hline \multicolumn{6}{|c|}{ Model Summary } \\
\hline Model & $\mathrm{R}$ & R Square & $\begin{array}{c}\text { Adjusted R } \\
\text { Square }\end{array}$ & $\begin{array}{l}\text { Std. Error of the } \\
\text { Estimate }\end{array}$ & Durbin-Watson \\
\hline 1 & $.600^{\mathrm{a}}$ & .360 & .343 & 4.561 & 1.549 \\
\hline
\end{tabular}

Berdasarkan hasil analisis diketahui nilai $\mathrm{DW}=1,549$ diantara -2 sampai dengan 2 yang berarti tidak terdapat/terjadi kesalahan autokorelasi.

\subsubsection{Analisis Regresi}

Untuk mengetahui variabel-variabel independen terhadap variabel dependen digunakan analisis kuantitatif dengan metode regresi linier berganda. Berdasarkan hasil perhitungan dengan menggunakan SPSS versi 20 diperoleh rekapitulasi hasil analisis regresi linier berganda seperti pada tabel dibawah ini

Tabel 10. Rekapitulasi hasil analisis regresi

\begin{tabular}{ccccc}
\hline \multicolumn{1}{c}{ Variabel } & Koefisien Regresi (b) & Beta & thitung & Sig t \\
\hline Constant & 12,890 & & 2,525 & 0,014 \\
Insentif & 0,730 & 0,428 & 4,574 & 0,000 \\
Budaya Kerja & 0,722 & 0,328 & 3,508 & 0,001 \\
\hline R & 0,600 & & & \\
R $^{2}$ & 0,360 & & \\
Adj. R & 0,343 & & \\
F & 21,912 & & & \\
Sig & 0,000 & & & \\
\hline
\end{tabular}

Model regresi linier berganda yang diperoleh dalam penelitian ini adalah sebagai berikut:

Keterangan:

$$
\mathrm{Y}=12,890+0,730 \mathrm{X}_{1}+0,722 \mathrm{X}_{2}+\mathcal{\Sigma}
$$

1. Nilai konstanta regresi sebesar 12,890 artinya jika semua variabel bebas memiliki nilai sama dengan nol, maka Y sebesar 12,890 .

2. Nilai koefisien regresi variabel pertama $\left(X_{1}\right)$ yaitu insentif adalah sebesar 0,730 artinya jika $X_{1}$ berubah satu satuan maka Y akan berubah sebesar 0, 730 dengan asumsi variabel bebas dan tetap.

3. Nilai koefisien regresi variabel kedua $\left(\mathrm{X}_{2}\right)$ yaitu budaya kerja adalah sebesar 0,722 artinya jika $\mathrm{X}_{2}$ berubah satu satuan maka Y akan berubah sebesar 0,722 dengan asumsi variabel bebas dan tetap.

\subsubsection{Uji Hipotesis}

Adapun uji hipotesis yang dikemukakan, anatara lain:

1. Hipotesis pertama

Berdasarkan uji t ternyata bahwa tingkat signifikan untuk insentif $\left(\mathrm{X}_{1}\right)$ adalah sebesar 4,574>1,66462 artinya variabel insentif $\left(\mathrm{X}_{1}\right)$ berpengaruh signifikan terhadap variabel Komitmen karyawan untuk tetap bekerja. $\mathrm{T}_{\text {hitung }}>\mathrm{T}_{\text {tabel. }}$. Jadi variabel insentif $\left(\mathrm{X}_{1}\right)$ berpengaruh secara parsial terhadap Komitmen karyawan untuk tetap bekerja. Dengan demikian $\mathrm{H}_{0}$ ditolak dan $\mathrm{H}_{\mathrm{a}}$ diterima maka hipotesis pertama diterima.

2. Hipotesis kedua

Berdasarkan uji t ternyata bahwa tingkat signifikan untuk budaya kerja $\left(\mathrm{X}_{2}\right)$ adalah sebesar 3,508>1,66462 artinya variabel budaya kerja $\left(\mathrm{X}_{2}\right)$ berpengaruh signifikan terhadap variabel Komitmen karyawan untuk tetap bekerja. $\mathrm{T}_{\text {hitung }}>\mathrm{T}_{\text {tabel, }}$, berpengaruh secara parsial terhadap Komitmen karyawan untuk tetap bekerja. Dengan demikian $\mathrm{H}_{0}$ ditolak dan $\mathrm{H}_{\mathrm{a}}$ diterima maka hipotesis pertama diterima. 
3. Hipotesis ketiga

Berdasarkan uji $\mathrm{f}$ ternyata insentif dan budaya kerja berpengaruh signifikan terhadap komitmen karyawan untuk tetap bekerja sebesar 21,912 .

\section{KESIMPULAN}

Berdasarkan hasil penelitian, insentif dan budaya kerja berpengaruh signifikan terhadap komitmen karyawan untuk tetap bekerja. Secara spesifik indikator penelitian ini meliputi insentif (X1) dan budaya kerja (X2) terhadap komitmen karyawan untuk tetap bekerja $(\mathrm{Y})$ akan dibahas sebagai berikut. Berdasarkan penelitian yang telah dilakukan diperoleh hasil bahwa insentif dan budaya kerja berpengaruh positif dan signifikan terhadap komitmen karyawan untuk tetap bekerja pada PT. Wana Sawit Subur Lestari 2. Menurut Harsono (1983: 128) bahwa insentif adalah setiap sistem kompensasai dimana jumlah yang diberikan tergantung dari hasil yang dicapai yang berarti menawarkan suatu insentif kepada pekerja untuk mencapai hasil yang lebih baik. Dengan memberikan insentif diharapkan karyawan mempunyi komitmen yang tinggi terhadap perusahaan. Sementara menurut Heidjrachman dan Husman (1992:161) mengatakan bahwa pengupahan insentif dimaksudkan untuk memberikan upah atau gaji yang berbeda. Hasil penelitian ini sejalan dengan teori yang dikemukakan (Shandur dalam Nasution,2006:24).Komitmen pegawai tidak akan tumbuh dengan sendirinya, adanya hubungan yang signifikan antara budaya kerja dengan komitmen kerja (Shandur dalam Nasution,2006:24). Budaya dianggap sebagai pemicu timbulnya komitmen pegawai karena budaya yang dibangun sejalan dengan nilai-nilai yang dianut pegawai. Pegawai yang mempunyai komitmen akan bersedia memberikan diri mereka dengan sukarela untuk memajukan satuan kerjanya. Hasil penelitian ini juga menunjukkan bahwa insentif dan budaya kerja berpengaruh positif dan signifikan terhadap komitmen karyawan untuk tetap bekerja pada PT Wana Sawit Subur Lestari 2.

\section{UCAPAN TERIMAKASIH}

Terima kasih disampaikan kepada pihak-pihak yang telah mendukung terlaksananya penelitian ini.

\section{REFERENCES}

Suharsimi, Arikunto. 2006. Prosedur Penelitian. Jakarta: Rineka Cipta.

Suharsimi Arikunto. 2002. Prosedur Penelitian Suatu Pendekatan Partek. Cetakan kesebelas. Edisi Revisi V. Jakarta: PT. Rineka Citpa.

Bangun, Wilson. 2012. Manajemen Sumber Daya Manusia. Jakarta: Erlangga.

Griffin, Ricky W. 2004. Management. Jakarta: Erlangga.

Kementrian PAN RI. Pedoman Pengembangan Budaya Kerja Aparatur Negara. Jakarta

Handoko, T. Hani. 2001. Manajemen Personalia Dan Sumber Daya Manusia (Edisi 2). Yogyakarta: Badan Penerbit Fakultas Ekonomi.

Hasibuan, Melayu S. P. 2001. Manajemen Sumber Daya Manusia. Jakarta: PT. Bumi Aksara.

Mangkunegara, Prabu. 2002. Manajemen Sumber Daya Manusia Perusahaan, Cetakan ke-2. Bandung: PT. Remaja Rosdakarya Offset.

Mangkuprawira, Sjafri. 2009. Komitmen Karyawan dan Budaya Kerja.

Nasution, Atikah Lailiyah. 2006. Pengaruh Budaya Kerja Terhadap Komitmen pegawai Negeri Sipil Pada Kantor Pelayanan Pajak Kisaran Medan: Program Strata 1 Jurusan Manajemen Universitas Sumatra Utara.

Ndraha. Taliziduhu. 2005. Manajemen Sumber Daya Manusia. Jilid 1. Jakarta: Institut Ilmu Pemerintahan.

Panggabean, S. Mutiara. 2002. Manajemen Sumber Daya Manusia. Jakarta: Ghalia Indonesia

Rivai, Veithzal. 2005. Manajemen Sumber Daya Manusia Untuk Perusahaan : dari Teori Ke Praktik. Jakarta: Raja Grafindo Persada.

Robbins, SP. 1996. Perilaku Organisasi : Konsep Kontroversi Aplikasi ED Indonesia. Jakarta: PT. Prenhallindo.

Schein, Edgar. Organization Psikology. Prentice Hill Inc. New Delhi.

Siagian, Sondang P. 2002. Fungsi-fungsi manajerial. Jakarta : Bumi Aksara.

Sudarmanto. 2009. Kinerja dan Pengembangan Kompetensi SDM Teori Dimensi Pengukuran dan Implementasi Dalam Organisasi. Yogyakarta Pustaka Pelajar.

Sugiyono. 2006. Metode Penelitan Bisnis. Bandung : CV Alfabeta.

Suharsini, Arikunto. 2000.Manajemen Penelitian. Jakarta : Rineka Cipta.

Sumadi, Suryabrata. 2008. Metodologi Penelitian. Jakarta: Raja Grafindo Pustaka.

Sunarto. 2005. Manajemen Karyawan. Jakarta: Amus.

Ndraha, Taliziduhu. 2003. Teori Budaya Organisasi Cetakan kedua Hal 80. Jakarta: PT. Rineka Cipta.

Truguno. 2002. Budaya Kerja. Jakarta: PT Golden trayon Press.

Triguno. 2004. Budaya Kerja: Menciptakan Lingkungan Yang Kondusif Untuk meningkatkan Produktivitas Kerja Ed. Jakarta: PT. Golden Trayon Press. 